\title{
Experimental Investigation to Study Effect of Polyester Fibre on Durability of HVFA Concrete through RCPT Method
}

\author{
Indrajit Patel ${ }^{1}, \mathrm{C}$ D Modhera Author ${ }^{2}$ \\ ${ }^{l}$ Gujarat Technological University, Gujarat, India \\ ${ }^{2} S$ V National Institute of Technology, Surat, India
}

\begin{abstract}
Global warming has emerged today as a life-threatening issue for the world. Since concrete is one of the most consumed material after water on the earth for infrastructure \& construction industries, a commendable contribution can be made by optimizing the use of cement and natural resources in concrete manufacturing. High volume Fly Ash (HVFA) concrete is one of the major developments since last two decade leading to utilization of Fly Ash in a bulk quantity and thereby reducing cement consumption and ultimately reducing emulsion of $\mathrm{CO} 2$ in order of one ton per a ton of cement. Durability of concrete structure is another important parameter effecting the sustainability of concrete technology in addition to minimizing use of virgin material. Experimental investigation has been carried out by authors to study effect of $12 \mathrm{~mm}$ triangular polyester fibre on engineering and durability properties of HVFA concrete. Engineering parameters include compressive and flexural strength, impact and abrasion resistance. Durability aspect is studied through Rapid Chloride Penetration Test (RCPT) as per ASTM C 1202 and comparative study for RCPT test is discussed for plain and fibre reinforced HVFA concrete in this article. The article describes durability parameters of HVFA concrete, methodology of RCPT, standards and test report of special additives to HVFA.
\end{abstract}

Keywords: - Durability, Fly ash, Fibre, RCPT

\section{INTRODUCTION}

The permeability of High Volume Fly Ash(HVFA) concrete is very low. The estimated permeability (hydraulic conductivity) of HVFA concrete is less than 10-13 m/s. As a comparison, normal Portland cement concrete with a W/C of 0.40 would have an estimated permeability of 10-12 m/s (Malhotra and Mehta, 2002). In general, the resistance of a reinforced concrete structure to corrosion, alkali aggregate expansion, sulfate and other forms of chemical attack depends on the water tightness of the concrete. HVFA concrete when properly cured is able to provide excellent water-tightness and durability (Mehta P K, 2004). The use of fly ash in concrete decreases the required water and this combined with the production of additional cementitious compounds leads to a low The porosity and discontinuous pore structure which reduces the permeability of the concrete (Estakhri and Saylak, 2004; Malhotra and Mehta, 2002). It is worth re-emphasizing that the permeability of HVFA concrete is greatly influenced by curing. Inclusion of structural or non structural fibre to overcome drawback of HVFA concrete like slow early age strength gaining, bleeding and segregation, poor resistance to tensile, abrasive and impact resistance needs a systematic study for its effect on durability parameters of HVFA concrete.

Following different tests are carried out to access the durability of HVFA concrete as per need and situation.

- Water permeability

- Resistance to freezing and thawing cycles, ASTM C-666-test procedure.

- Resistance to de-icing-salt scaling, ASTM C -672 test method

- Resistance to the penetration of chloride icons ASTM C 1202 and corrosion of steel reinforcement

- Carbonation ASTM C 192 /C 192M-98

- Resistance to sulphate attack

- Control expansion due to alkali silica reaction

The present experimental work includes study of different durability parameters, test methodology and Rapid Chloride Penetration Test in detail as per ASTM C 1207.

\section{Rapid Chloride Penetration Test}

This test method was originally developed by the Portland Cement Association, under a research program paid for by the Federal Highway Administration (FHWA). The original test method may be found in FHWA/RD-81/119, Rapid Determination of the Chloride Permeability of Concrete." Since the test method was developed, it has been modified and adapted by various agencies and standard's organizations. These include: 
- AASHTO T277, "Standard Method of Test for Rapid Determination of the Chloride Permeability of Concrete" - ASTM C1202, "Standard Test Method for Electrical Indication of Concrete's Ability to Resist Chloride Ion Penetration"

The test procedure developed by the researcher as per AASHTO T277 and ASTM C1202 is described below. Test method involves obtaining a $100 \mathrm{~mm}$ (4 in.) diameter core or cylinder from the concrete being tested. A $50 \mathrm{~mm}$ (2 in.) specimen is cut from the sample. The side of the cylindrical specimen sample is coated with epoxy, and after the epoxy is dried, it is put in a vacuum chamber for 3 hours. The specimen is vacuum saturated for 1 hour and allowed to soak for 18 hours. It is then placed in the test device (Fig.1). The left-hand side (-) of the test cell is filled with a $3 \% \mathrm{NaCl}$ solution. The right-hand side (+) of the test cell is filled with $0.3 \mathrm{~N} \mathrm{NaOH}$ solution. The system is then connected and a 60 -volt potential is applied for 6 hours. Readings are taken every 30 minutes. At the end of 6 hours the sample is removed from the cell and the amount of coulombs passed through the specimen is calculated. The test set up is shown in Fig.1

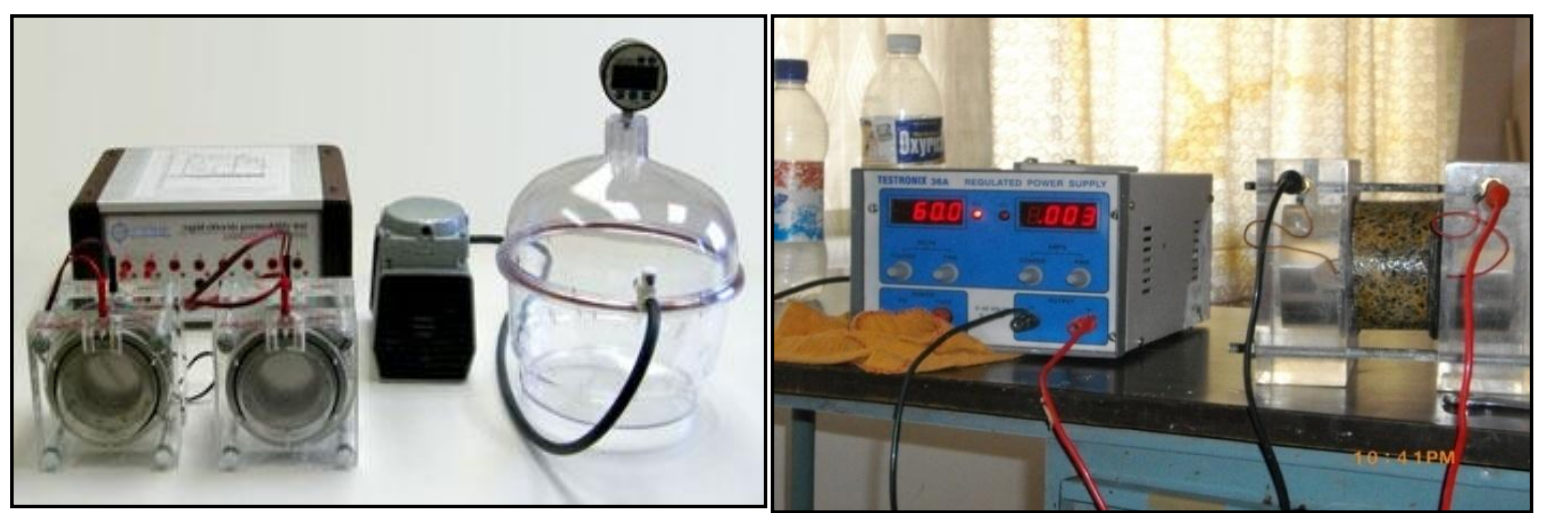

Fig.1 RCPT Test Equipment and Set Up.

The test results are compared to the values in the TABLE .1. This chart was originally referenced in FHWA/RD-81/119 and is also used in AASHTO T277-83 and ASTM C1202 specifications.

Table 1 Standard as per ASTM C 1202

\begin{tabular}{|c|c|}
\hline Charge passed coulombs & Chloride ion penetrability \\
\hline$>4000$ & High \\
\hline $2000-4000$ & Moderate \\
\hline $1000-2000$ & Low \\
\hline $100-1000$ & Very low \\
\hline$<100$ & Negligible \\
\hline
\end{tabular}

\section{METHODOLOGY}

\section{Material}

Cement and Fly Ash: Ordinary Portland cement of 53 grades available in local market is used in the investigation. The cement used has been tested for various proportions as per IS 4031-1988 and found to be confirming to various specifications of are IS 12269-1987. Class F fly ash confirming to BIS 3812-2003 was used as mineral admixture. "Fig.2" shows scanning electron microscopic view of fly ash.

Coarse aggregate: Crushed angular granite metal of $20 \mathrm{~mm}$ and $10 \mathrm{~mm}$ size from a local source was used as coarse aggregate in the proportion of 60:40. The specific gravity of 2.86 and fineness modulus 7.13 was used.

Fine aggregate: Local River sand confirming to zone-II was used as fine aggregate. The specific gravity of 2.60 and fineness modulus 2.86 was used in the investigation.

Polyester Fibre: $12 \mathrm{~mm}$ size triangular-Tribodal shaped polyester fibre confirming to type III fibres under ASTM C: 1116 were used as a supplementary reinforcing material to enhance the mechanical properties of hardened concrete. The scanning electron microscopic view is shown in "Fig.2"

Admixtures: High range water reducing admixtures for fibre reinforced HVFA samples Poly carboxylate based super plasticizer was used. 


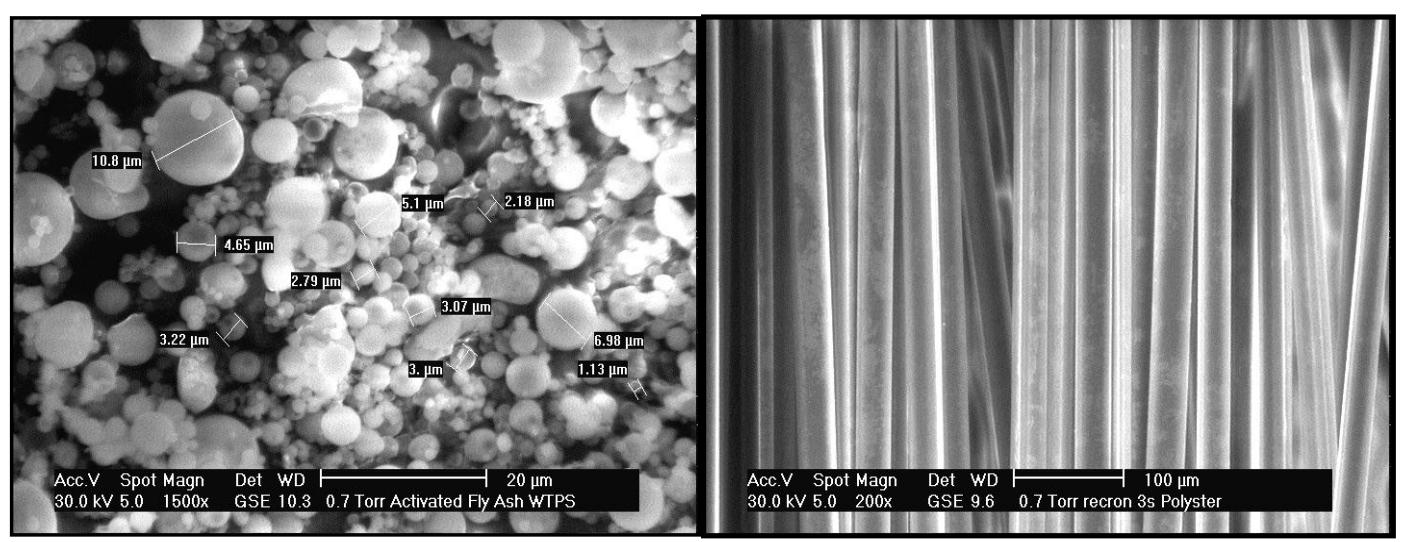

Fig.2 Scanning Electron Microscope View of Fly Ash and Fibre

\section{Mix Design}

Based on guidelines provided by CANMET for HVFA trail mix were prepared for each design mix to achieve desired workability with controlled water to binder ration. Water to binder ratio kept between 0.25 to 0.38 for richer and moderate strength. The dosage of plasticizer was adjusted between 0.80 to 1.00 percentages of cementing material by mass to take care for inclusion of fibre as well as controlling water to binder ration for achieving slump values between 85 to $100 \mathrm{~mm}$ at 60 minutes retention time. From test results of trial mix at 7 , 28 days design mix for M25, M30,M35 and M40 were prepared. The mix design for experimental work is presented in TABLE. 2

Table.2 Design Mix

\begin{tabular}{|c|c|c|c|c|c|c|c|c|c|c|c|}
\hline Sample & $\mathrm{C}$ & Fa & $\mathrm{C}+\mathrm{Fa}$ & W & SP & $\begin{array}{c}\mathrm{W} / \\
\mathrm{C}+\mathrm{Fa}\end{array}$ & FA & $\begin{array}{c}20 \\
\mathrm{~mm}\end{array}$ & $\begin{array}{c}10 \\
\mathrm{~mm}\end{array}$ & $\underset{\mathrm{mm}}{\text { Slump }}$ & $\begin{array}{l}\text { Density } \\
\mathrm{kg} / \mathrm{m}^{3}\end{array}$ \\
\hline A.10 & 195 & 195 & 390 & 120 & 2.4 & 0.31 & 642 & 761 & 441 & 90 & 2394.4 \\
\hline$A 20^{-}$ & 202 & 248 & $450^{\circ}$ & 125 & 3.6 & 0.28 & $600^{\circ}$ & 853 & $379^{-}$ & $75^{-}$ & 2410.6 \\
\hline $\mathrm{A} 3 \mathrm{O}^{-}$ & $180^{-}$ & $270^{-}$ & $-450^{--}$ & 140 & 3.6 & $0.31^{-}$ & 591 & 839 & 373 & $110^{--}$ & 2396.6 \\
\hline
\end{tabular}

\begin{tabular}{|c|c|c|c|c|c|c|c|c|c|c|c|}
\hline Sample & $\mathrm{C}$ & Fa & $\mathrm{C}+\mathrm{Fa}$ & W & SP & W/B & FA & $\begin{array}{c}20 \\
\mathrm{~mm}\end{array}$ & $\begin{array}{c}10 \\
\mathrm{~mm}\end{array}$ & $\begin{array}{c}\text { Slump } \\
\mathrm{mm}\end{array}$ & $\begin{array}{c}\text { Density } \\
\mathrm{kg} / \mathrm{m} 3\end{array}$ \\
\hline B10 & 225 & 225 & 450 & 130 & 3.4 & 0.29 & 554 & 757 & 432 & 95 & 2326.4 \\
\hline $\mathrm{B} 20^{\circ}$ & $225^{-}$ & 275 & $500^{-1}$ & $130^{\circ}$ & $4.0^{-}$ & 0.26 & 585 & 850 & $351^{-}$ & $90^{-}$ & $2417.0^{\circ}$ \\
\hline $\mathrm{B} 30^{-}$ & $200^{\circ}$ & 300 & $500^{-}$ & 145 & $4.0^{\circ}$ & 0.30 & 568 & 825 & 341 & $110^{-}$ & 2383.0 \\
\hline
\end{tabular}

\begin{tabular}{|c|c|c|c|c|c|c|c|c|c|c|c|}
\hline Sample & $\mathrm{C}$ & $\mathrm{Fa}$ & $\mathrm{C}+\mathrm{Fa}$ & W & SP & $\begin{array}{c}\mathrm{W} / \\
\mathrm{C}+\mathrm{Fa}\end{array}$ & FA & $\begin{array}{c}20 \\
\mathrm{~mm}\end{array}$ & $\begin{array}{c}10 \\
\mathrm{~mm}\end{array}$ & $\underset{\mathrm{mm}}{\text { Slump }}$ & $\begin{array}{c}\text { Density } \\
\mathrm{kg} / \mathrm{m} 3\end{array}$ \\
\hline $\mathrm{C} 10$ & 250 & 250 & 500 & 140 & 4.0 & 0.28 & 554 & 757 & 432 & 100 & 2387.00 \\
\hline $\mathrm{C}_{20}$ & 247 & $303^{-}$ & $550^{--}$ & $138^{-}$ & 3.8 & $0.28^{-}$ & 525 & $848^{-}$ & $336^{-}$ & $95^{--}$ & $2400.90^{-}$ \\
\hline $\mathrm{C} 3 \mathrm{O}^{-}$ & $220^{-}$ & $-330^{--}$ & $550^{-1}$ & $137^{-}$ & $3.8^{-}$ & $0.25^{-1}$ & $-514^{-}$ & 826 & 327 & $90^{--}$ & $2358.30^{-}$ \\
\hline
\end{tabular}

\begin{tabular}{|c|c|c|c|c|c|c|c|c|c|c|c|}
\hline \multicolumn{12}{|l|}{ M40 } \\
\hline Sample & $\mathrm{C}$ & $\mathrm{Fa}$ & $\mathrm{C}+\mathrm{Fa}$ & W & SP & $\begin{array}{c}\mathrm{W} / \\
\mathrm{C}+\mathrm{Fa}\end{array}$ & FA & $\begin{array}{l}20 \\
\mathrm{~mm}\end{array}$ & $\begin{array}{c}10 \\
\mathrm{~mm}\end{array}$ & $\begin{array}{c}\text { Slump } \\
\text { mm }\end{array}$ & $\begin{array}{l}\text { Density } \\
\mathrm{kg} / \mathrm{m} 3\end{array}$ \\
\hline D10 & 280 & 280 & 560 & 150 & 5.6 & 0.27 & 501 & 761 & 415 & 110 & 2392.60 \\
\hline D20 & 270 & 330 & 600 & 150 & 4.2 & 0.25 & 485 & 820 & 318 & $110^{-}$ & 2377.60 \\
\hline D30 & 240 & 360 & 600 & 144 & 4.2 & 0.35 & -471 & 839 & 319 & 100 & 2377.20 \\
\hline
\end{tabular}

Mix: A -M25 B-M30, C-M35, D-M40, Fly ash Content: $1=50 \% 2=55 \% 3=60 \%$ Fibre Content: $0=0 \%$,

$$
1=0.15 \%, 2=0.25 \%
$$




\section{Experimental Work}

Design mix comprises of cement replacement by 50,55 and 60 percentage by mass with class $\mathrm{F}$ fly ash. The $12 \mathrm{~mm}$ triangular shaped polyester fibres were added at the rate of $0.15 \%$ and $0.25 \%$ by mass of cementing material. For each design mix the samples for RCPT measuring $100 \mathrm{~mm}$ diameter and $5 \mathrm{omm}$ thickness were casted as per ASTM 1202 specification for plain and fibre reinforced HVFA condition. The experiment was carried out at 28 and 56 days of curing. "Fig. 3" shows test sample and epoxy coated sample place in RCPT equipment ready for testing..
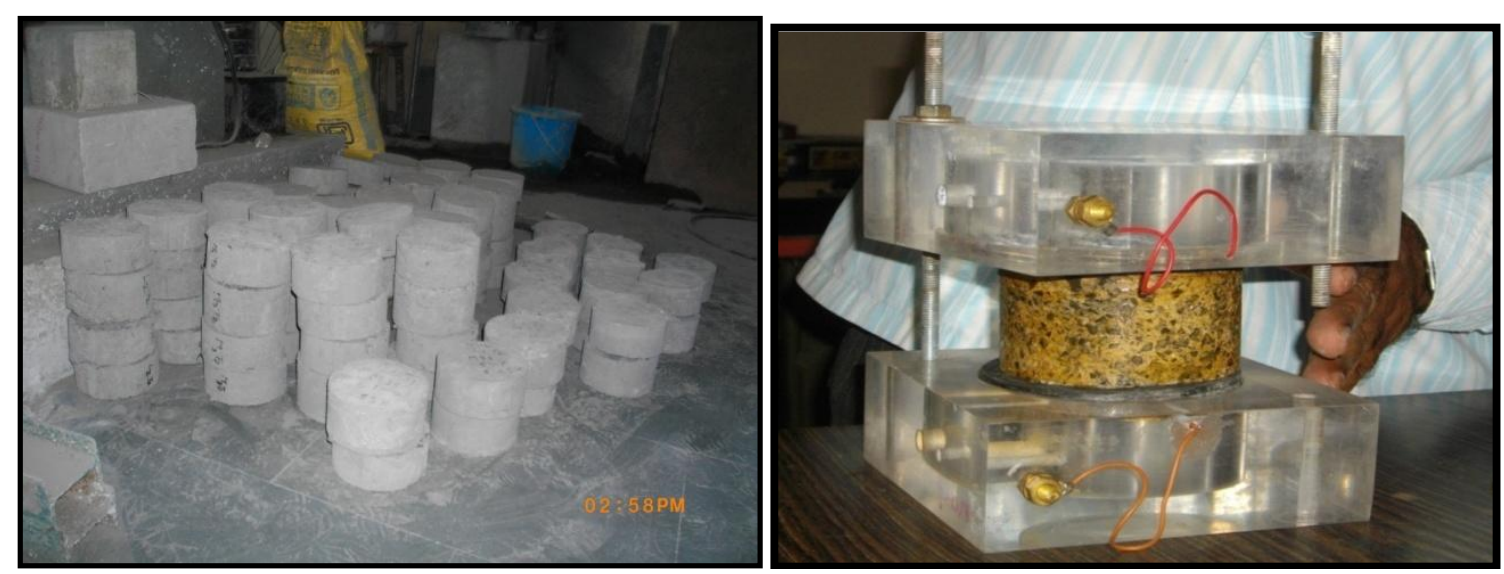

Fig.3 RCPT Test Specimen and Test arrangement

III.

RESULT AND DISCUSSION

As specified in ASTM C 1202 the current passed was measured at an interval of 15min for six hours for each sample and readings in Columbs were tabulated as shown in TABLE 3. The comparative study for different mix ,inclusion of fibre , replacement of cement at age of 28 and 91 days are shown graphically in " Fig.4".

Table. 3

M25 Grade

\begin{tabular}{|c|c|c|c|c|c|c|}
\hline Fly Ash/Fibre \% & \multicolumn{2}{|c|}{$\mathbf{5 0}$} & \multicolumn{2}{c|}{$\mathbf{5 5}$} & \multicolumn{2}{c|}{$\mathbf{6 0}$} \\
\hline Days & $\mathbf{2 8}$ & $\mathbf{9 1}$ & $\mathbf{2 8}$ & $\mathbf{9 1}$ & $\mathbf{2 8}$ & $\mathbf{9 1}$ \\
\hline $\mathbf{0 . 0 0}$ & 917.20 & 572.40 & 903.55 & 501.20 & 869.70 & 459.90 \\
\hline $\mathbf{0 . 1 5}$ & 837.10 & 524.00 & 816.20 & 468.45 & 811.20 & 403.70 \\
\hline $\mathbf{0 . 2 5}$ & 806.15 & 460.35 & 800.00 & 353.70 & 769.35 & 349.35 \\
\hline
\end{tabular}

M30 Grade

\begin{tabular}{|c|c|c|c|c|c|c|}
\hline Fly Ash/Fibre \% & \multicolumn{2}{|c|}{$\mathbf{5 0}$} & \multicolumn{2}{c|}{$\mathbf{5 5}$} & \multicolumn{2}{c|}{$\mathbf{6 0}$} \\
\hline Days & $\mathbf{2 8}$ & $\mathbf{9 1}$ & $\mathbf{2 8}$ & $\mathbf{9 1}$ & $\mathbf{2 8}$ & $\mathbf{9 1}$ \\
\hline $\mathbf{0 . 0 0}$ & 857.70 & 561.50 & 868.90 & 498.75 & 789.00 & 512.30 \\
\hline $\mathbf{0 . 1 5}$ & 817.35 & 512.45 & 834.50 & 436.50 & 804.67 & 397.60 \\
\hline $\mathbf{0 . 2 5}$ & 805.00 & 448.60 & 768.00 & 379.12 & 772.40 & 361.00 \\
\hline
\end{tabular}

\section{M35 Grade}

\begin{tabular}{|c|c|c|c|c|c|c|}
\hline Fly Ash/Fibre \% & \multicolumn{2}{|c|}{$\mathbf{5 0}$} & \multicolumn{2}{c|}{$\mathbf{5 5}$} & \multicolumn{2}{c|}{$\mathbf{6 0}$} \\
\hline Days & $\mathbf{2 8}$ & $\mathbf{9 1}$ & $\mathbf{2 8}$ & $\mathbf{9 1}$ & $\mathbf{2 8}$ & $\mathbf{9 1}$ \\
\hline $\mathbf{0 . 0 0}$ & 827.90 & 477.20 & 789.60 & 422.20 & 706.35 & 342.90 \\
\hline $\mathbf{0 . 1 5}$ & 813.75 & 432.90 & 768.25 & 409.70 & 700.50 & 348.90 \\
\hline $\mathbf{0 . 2 5}$ & 746.90 & 397.30 & 723.58 & 379.90 & 698.00 & 334.60 \\
\hline
\end{tabular}

\section{M40 Grade}

\begin{tabular}{|c|c|c|c|c|c|c|}
\hline Fly Ash/Fibre \% & \multicolumn{2}{|c|}{$\mathbf{5 0}$} & \multicolumn{2}{c|}{$\mathbf{5 5}$} & \multicolumn{2}{c|}{$\mathbf{6 0}$} \\
\hline Days & $\mathbf{2 8}$ & $\mathbf{9 1}$ & $\mathbf{2 8}$ & $\mathbf{9 1}$ & $\mathbf{2 8}$ & $\mathbf{9 1}$ \\
\hline $\mathbf{0 . 0 0}$ & 734.00 & 351.00 & 695.90 & 369.00 & 678.12 & 355.50 \\
\hline $\mathbf{0 . 1 5}$ & 678.50 & 341.70 & 654.00 & 339.45 & 634.00 & 336.85 \\
\hline $\mathbf{0 . 2 5}$ & 602.10 & 318.60 & 587.10 & 344.60 & 548.10 & 324.40 \\
\hline
\end{tabular}



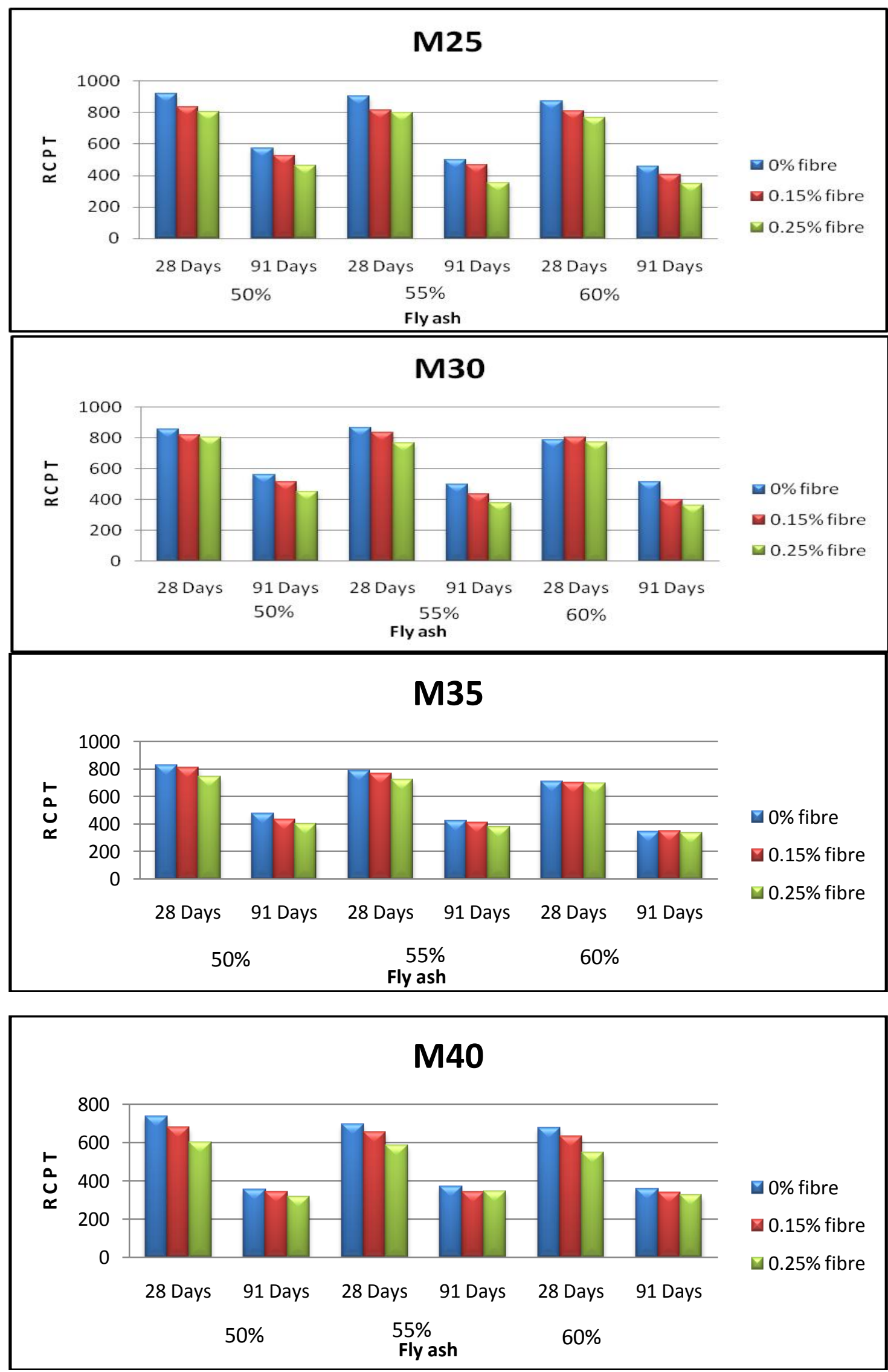

Fig.4 Comparative Study of RCPT Results 


\section{CONCLUSIONS}

From Table 3 and fig. 4 following observations are made for the current experimental investigations.

a) For plain HVFA samples it is observed that RCPT value at 28 days is on average $858.10,838,17,774,30,702,67$ for M25, M30, M35, and M40 respectively. It is of order 510.67, 523.07, 413.65 and 358.50 at 91 days age of samples.

b) Study shows for plain HVFA samples the chloride penetration resistance increases in order of $40.55 \%$, $43.25 \%, 46.64 \%$ and $49.00 \%$ for M25 to M40 mix respectively.

c) At 91 days age from table 5.23 to 5.26 following observations are made to compare plain and fibre reinforced HVFA samples with average values for 50\% 55\% and 60\% cement replacement.

- Inclusion of $0.15 \%$ fibre reduces the chloride permeability in order of $9.00,14.57,4.74,5.44 \%$ for grade $\mathrm{M} 25, \mathrm{M} 30, \mathrm{M} 35$ and $\mathrm{M} 40$ respectively.

- It is in order of $24.30,24.38,10.30$, and 8.29 respectively for M25 to M40 grade samples with $0.25 \%$ fibre inclusion.

- With $0.15 \%$ to $0.25 \%$ fibre, percentage increase in chloride resistance is in order of $62.10,40.23$, 53.98, and 34.37 for M25M30M35 and M40 grade respectively.

d) Measurement of current for six hours in all samples at an interval of $15 \mathrm{~min}$ found to be almost constant which reflects uniform dense mix and lower permeability in the concrete.

e) All samples with and without fibre inclusion shows very low permeability as per ASTM C1202.

f) Richer mix and higher replacement of cement gives excellent resistance at latter ages of samples.

\section{Journal Papers:}

\section{REFERENCES}

[1] A. Bilodeau, V. Sivasundaram, K.E. Painter, V.M. Malhotra, Durability of concrete incorporating high volumes of fly ash from sources in the USA, ACI Mater. J. 91 (1) (1994) 3- 12.

[2] A. Bisaillon, R. Michel, V.M. Malhotra,"Performance of high-volume fly ash concrete in large experimental monoliths", ACI Mater. J. 91 (2) (1994) 178-187.

[3] Chandramouli K et.al ,"Rapid Chloride Permeability Test For Durability Studies On Glass Fibre Reinforced Concrete", ARPN Journal of Engineering and Applied Sciences, Vol. 5, No. 3, March 2010,pp 67-71

Books:

[4] Gambhir, M. L Concrete Technology,( Tata Mc-Graw Hills, 2004).

[5] Shetty, M.S. Concrete Technology,(S.Chand \& Company Ltd., edition 2010 pp.1-503).

Theses:

[6] Donald Burden, , Theory The Durability of Concrete Containing High Levels of Fly Ash. Master of Science in Engineering Dissertation, University of New Brunswick, 2003.

Proceedings Papers:

[7] Gebler, S.H., and Klieger, Paul, "Effect of Fly Ash on Physical Properties of Concrete", Proceedings of the CANMET/ACI Second International Conference on the Use of Fly Ash, Silica Fume, Slag, and Natural Pozzolana in Concrete, Madrid, Spain, V.M. Malhotra, Ed., Vol.1,ACI Special Publication No. SP-91, 1986, pp. 1-50.

\section{Standards:}

[8] ASTM C 1116-97, Standard specification for Fiber Reinforced concrete and shortcrete.

[9] ASTM C 1202-09, Standard test method for electrical indication of concrete's ability to resist chloride ion penetration.

[10] BIS 10262: 1982 Recommended guidelines for concrete mix design.

[11] BIS 3812:2003, Specification for Fly Ash for Use as Pozzolana and Admixture. 